\title{
The Practice of Female Circumcision in the Working Area of Muara Tebo Health Center, Tebo Tengah, Jambi Province in 2011 \\ Rini Kurniawati $i^{1}$ and Mila Herdayati² \\ ${ }^{1}$ Postgraduate Student Faculty of Public Health, Universitas Indonesia, Depok, Indonesia \\ ${ }^{2}$ Faculty of Public Health, Universitas Indonesia, Depok, Indonesia
}

\section{Abstract}

The practice of female circumcision is still in progress today. The purpose of this study was to know the description of the method of female circumcision and factors related to the behavior of female circumcision in the working area of Muara Tebo Health Center, Tebo Tengah, Jambi Province in 2011. This study used primary data. The type of quantitative research with cross-sectional design and the results were corroborated by qualitative analysis. The population of the study was that all mothers of the girls

Corresponding Author: Rini Kurniawati

hayuri_rini@yahoo.com

Received: 26 December 2018 Accepted: 23 February 2019 Published: 7 March 2019

Publishing services provided by Knowledge E

(c) Rini Kurniawati and Mila Herdayati. This article is distributed under the terms of the Creative Commons

Attribution License, which permits unrestricted use and redistribution provided that the original author and source are credited.

Selection and Peer-review under the responsibility of the $2 \mathrm{nd}$ International Meeting of Public Health 2016 Conference Committee.

\section{G OPEN ACCESS} between 0-6 months of age who reside in the Health Center (Puskesmas) in Muara Tebo. The size of the total sample of respondents was 85 . The results showed that $76.5 \%$ of respondents had implemented female genital circumcision on the girl of them and use of midwives only $33.8 \%$. Therefore, the socialization needed new regulations concerning the implementation of circumcision of women as stipulated in Permenkes N0.1636/Menkes/Per/XI/2010 to health workers. Religious leaders/community leaders should give an insight that female circumcision was not harmful both to physical and psychological health in the future.

Keywords: Female circumcision; practice; regulation

\section{Introduction}

Genital cutting or genital mutilation is an ancient practice that is carried out by various communities around the world for reasons of socio-cultural, and to this day remains. Female Genital mutilation (FGM) - is defined by the WHO and the United Nations (UN) as "Removal of part or all the external female genitalia or another injury to the female genital organs for non-medical reasons." FGM is a tradition that is rooted in many communities in 28 countries in Africa and some countries in Asia and the Middle East. Today, in the world, there are approximately $130-140,000,000$ girls and women who have undergone surgery / FGM and 3 million girls are at risk of the practice each year (WHO 2011). 
In Indonesia, the practice of female circumcision is divided into two main groups: "symbolic" that is the type where there is no incision or excision, accounting for about $28 \%$ of cases and the rest is the second type is "dangerous", which involves an incision and excision of as much as $72 \%$ of cases. The prevalence of female circumcision in Indonesia is $86-100 \%$. Female circumcision in Padang Pariaman and Serang is done when a new child is born but in the area of Gorontalo, Makassar and Bone, it is generally done by the age of 5-9 years (Budiharsana et al. 2004).

The tendency of female circumcision shift implementer power of the midwife and excisor for health workers called medicalization. Medicalization of female circumcision is one aspect that maintains the continuity of the practice of female circumcision in Indonesia, in addition to issues of religious and cultural preservation.

Although it is opposed in many countries, considering as a violation in the reproductive rights of women, the practice of female genital mutilation is still widely practiced. By the Indonesian government, female circumcision is not prohibited but should be only done in certain parts. Rules regarding female circumcision is can be found in Permenkes No.1636 / Menkes / Per / XI / 2010. This rule is designed to protect women from genital mutilation illegal and life-threatening reproductive system.

The absence of data on the practice of female circumcision in Muara Tebo Health Center made researchers want to know the description of female circumcision practices as well as factors related to the behavior of female circumcision.

\section{Methods}

This study was quantitative research using cross-sectional study design and to reinforce the results of this study also used qualitative research. The population of this research was 85 mothers who had given birth to a daughter from August 2010 through January 2011 in Muara Tebo Heath Center. Sample of this research was a total sampling of 85 peoples. Informants in this study were six midwives working in the area of Muara Tebo Health Center. The primary data were obtained from interviews with respondents using a questionnaire adapted from research Budiharsana (2002). For primary qualitative primary data usedin-depth interviews conducted with the needs of researchers in the group of informants about the behavior of female circumcision. The data were processed using SPSS version 13.0 through the stages of data processing, namely editing, coding, entry, tabulating. Processing of qualitative data collected from recordings using a voice recorder and moved in written form (transcript). 


\section{Results}

The variables examined in this study were age, education level, religion, level of knowledge about female circumcision, attitude, family support, the support of religious leaders, implementers and behavior of female circumcision in Muara Tebo Health Center 2011. The results were shown as follows.

\section{Discussions}

The results of this study indicated that the implementation of female circumcision had no relationship with the mother's age, number of children, but the mother's education influenced the decision to behave and act. It was also influenced by other factors such as trust, in this case the majority of respondents Islamic religion, because element this religion contributed to the implementation of female circumcision and also they were encouraged by the support of family and religious leaders, causing the continuation of this practice of female circumcision still remained. (Green 1980).

All respondents ( 85 people) in the study showed that $76.5 \%$ of them had known to carry out female circumcision on her young daughter at the age of 40 days after birth $(60 \%)$ and $60 \%$ of them did the circumcision because of the their believes. The practice of female circumcision was mostly often done by excisors $(66.2 \%)$, reinforced by the testimony of a midwife.

\section{"Most of mothers brought her daughter to me for circumcision and sometimes people from the village next door was also asked for circumcision in my place because her midwife did not want to do it" (midwife A). The point is that she is Muslim, must be circumcised, either by the shaman or me."}

Therefore, Permenkes No. 1636 / Menkes / Per / XI / 2010 could be expected to be as a reference in the implementation of the practice female circumcision by trained medical personnel, to protect girls from genital mutilation actions that were harmful to the female organs.

\section{Conclusions}

Based on the results of research on the practice of female circumcision in Puskesmas Muara Tebo, District Tebo Tengah, Tebo regency, Jambi province in 2011, the practice of female circumcision was still widely practiced on the grounds of religious persecution, carried out by a excisors by using non-sterile tools. Therefore, Permenkes No.1636 / 
TABLE 1: Distribution of Respondents Based on the Characteristics of The Practice of Female Circumcision.

\begin{tabular}{|c|c|c|}
\hline Characteristics / categories & $\mathbf{n}$ & $\%$ \\
\hline \multicolumn{3}{|l|}{ Age } \\
\hline $15-20$ years & 11 & 12.9 \\
\hline $21-25$ years & 18 & 21.2 \\
\hline $25-30$ years & 36 & 42.4 \\
\hline 31 - 35 years & 18 & 21.2 \\
\hline $36-40$ years & 2 & 2.4 \\
\hline \multicolumn{3}{|l|}{ Education } \\
\hline Pass Elementary School & 35 & 41.2 \\
\hline Pass Junior High School & 25 & 29.4 \\
\hline Pass Senior High School & 17 & 20 \\
\hline Pass Collage & 8 & 9.4 \\
\hline \multicolumn{3}{|l|}{ The number of girls held } \\
\hline One people & 61 & 71.8 \\
\hline Two peoples & 21 & 24.8 \\
\hline$>2$ peoples & 3 & 3.5 \\
\hline \multicolumn{3}{|l|}{ Religion } \\
\hline Islam & 76 & 89.4 \\
\hline Chirstian & 9 & 10.6 \\
\hline \multicolumn{3}{|l|}{ Knowledge } \\
\hline Good & 16 & 18,8 \\
\hline Not Good & 69 & 81,2 \\
\hline \multicolumn{3}{|l|}{ Attitude } \\
\hline Positive to female circumcision & 55 & 64.7 \\
\hline Negative to female circumcision & 30 & 35.3 \\
\hline \multicolumn{3}{|l|}{ The Attitude of female circumcision } \\
\hline Circumcision & 65 & 76.5 \\
\hline Not Circumcision & 20 & 23.5 \\
\hline \multicolumn{3}{|l|}{ Implementer Power } \\
\hline Excisors & 43 & 66.2 \\
\hline Midwife & 22 & 33.8 \\
\hline \multicolumn{3}{|l|}{ Support of Family } \\
\hline Supporting Families Circumcision & 55 & 64.7 \\
\hline Not Supporting Families Circumcision & 30 & 35.3 \\
\hline \multicolumn{3}{|l|}{ Support of Religion Figure } \\
\hline Support & 61 & 71.8 \\
\hline Not Support & 24 & 28.2 \\
\hline
\end{tabular}

Menkes / PPER / 2010 cited that circumcision should be performed by trained medical personnel to ensure the practice of female circumcision was safe for the genitals of girls and children's mental health in the future. 


\section{References}

[1] Budiharsana, M, dkk. 2004. Research Report: Female Circumcision in Indonesia: Implication and Possible Intervention to Uphold Women's Health Right, Population Council, Jakarta.

[2] WHO.2011. An Update on WHO's Work on Female Genital Mutilation (FGM) Progress Report. Geneva

[3] Green, Lawrence, et al. 1980. Health Education Planning A Diagnostic edition of the translation by Zulazmi Mandi, Zarfil Tafel, Sudarti Kresno. Jakarta: FKM UI

[4] Menkes RI. Permenkes RI No.1636 / Menkes / PPER / 2010. Female Genital Circumcision (2010). Taken from http://hukor.depkes.go.id/uploads/produk_hukum/ PMK\{\%\}20No.\{\%\}201636\{\%\}20ttg\{\%\}20Sunat\{\%\}20Perempuan.pdf 